\title{
ANALYSIS OF SUBVENTIONS FOR AGRICULTURE IN REPUBLIC OF SERBIA AND REPUBLIC OF SRPSKA
}

\author{
Ljiljana Jović ${ }^{1}$, Nada Kosanović2 ${ }^{2}$ Predrag Vukadinovic ${ }^{3}$
}

\begin{abstract}
Summary
In this paper, a comparative analysis of subventions for agriculture and rural development is conducted, based on the budgets of Republic of Serbia and Republic of Srpska. Based on the analysis of the gross value added and the subvention amount in the period 2008-2013, it is concluded that there is no country with the causativelyconsequent connection between the subvention volume and gross value added which ensigns to inadequate policy of stimulations.

Besides that, it is noticed that there is no clear trend in the level of assets appropriation, as well as the structure of subvention beneficiaries, which refers that the policy of agricultural stimulation and village in none of the countries has the label of long-term elaborated goals, but it is more the product of current movements in public revenues, i.e. short-term defined political-economic priorities.
\end{abstract}

Key words: Agriculture, Subventions, Republic of Serbia, Republic of Srpska

JEL: E62, H24, Q14

\section{Introduction}

The food assurance is today one of the most important strategic goals everywhere in the world. Republic of Serbia and Republic of Srpska identified the agriculture and rural development as the areas of special interest for the growth of gross-social (Cvijanović, Mihailović, Vuković, 2014), and the available resources in this area are considered to be among the most important available resources.

1 Ljiljana Jović, Ph.D., Associate Professor, Novi Sad Business School, Vladimira Perića Valter Street no. 4, 21000 Novi Sad, Republic of Serbia, Phone: +381 65608 916, E-mail: joviclj@hotmail.rs

2 Nada Kosanović, Ph.D., Science Researcher, Institute for Science Application in Agriculture, Bulevar Despota Stefana no. 68B, Belgrade, Republic of Serbia, Phone: + 3816424086 53, E-mail: nada.kosanovic@gmail.com

3 Predrag Vukadinović, Ph.D., Assistant Professor, University Singidunum, Faculty of Business Belgrade, Danilova Street no. 32, Belgrade, Republic of Serbia, Phone: +381 63 216 908, E-mail: pvukadinovic@singidunim.ac.rs

EP 2015 (62) 4 (963-974) 
According to that, it is expected to conduct the adequate policy of agricultural and village support firstly through budget expenditures. Stable and constantly growing budget expenses in this area refer to the permanent organ appropriation of the economic policy to develop and strengthen the agricultural production sector.

In our work we conduct the expenses analysis of the subventions in Republic of Srpska and Republic of Serbia in the period from 2008-2013, based on which it can be concluded about the agrarian support and the quality of agrarian policy, as well as the comparison of the countries observed, according to this parameter.

\section{Data sources and used methodology}

In this paper, with the analysis of the statistical data, firstly the analysis of the subvention influence to the gross value added in agriculture during the observed years is conducted, followed by the comparative analysis of the budget expenses to the subventions in agriculture and its effects in Republic of Serbia and Republic of Srpska.

Besides that, by the usage of the parallel-legal method the legal background is analyzed, i.e. the security of all the legal solutions, which enables the subvention distribution in a legal and rightful way, stimulating the balanced development of all agricultural sectors.

Based on the analysis of the given points, the conclusions on the effectiveness of the republican subventions in both economies are made, so the certain directions are given for the future expenses.

The official statistic data were used for the analysis. The data in the gross-social product and gross value added in the agriculture in Republic of Serbia are taken from the Strategy of agriculture and rural development of Republic of Serbia for the period from 2014-2020. The data on the subventions are taken from the Bulletin of public finances no 102 .

The data used for Republic of Srpska which refer to gross-social product and gross value added are from the website of the Investment-development bank, i.e. the official statistics.

The data on the subvention participation for the agricultural production in the total budget expenses are from author's calculations and based on the Law on budgets for every observed year. The points are taken from the adopted budgets of Republic of Srpska for the referred year. The calculation was performed by calculating subvention part (from the common budget part under the name the Subvention for the stimulation of the development of agriculture and village, budget code 414100 , i.e. 614400 according to the economic classification) in the total budget expenses of the Republic.

\section{The significance of the subvention for the development of agriculture and village in Republic of Srpska}

The main economic potential of the Republic of Srpska beside hydro potential and mineral raw materials is considered to be the fertile land and forests. 
Republic of Srpska has significant surfaces of fertile land. The availability of the agricultural surfaces is estimated to be around 0.952 hectares per inhabitant. The agricultural production and agricultural services are the occupation of the 221,000 households in which there are around 800,000 inhabitants which is around $57.1 \%$ of the total population. (The data downloaded from the webpage www.irbrs.org, entered $1^{\text {st }}$ November 2014)

However, the available capacities are not used enough. From the point of exchange, the annual import of the agricultural products is on the level of 350 million dollars, while the export is 30 million dollars, which shows that the cover of export by import is around $87 \%$ (The strategy of the agricultural development of Republic of Srpska, 2006).

The review of the agricultural participation in the regeneration of the gross-social product is given in the following table.

Table 1. The agricultural participation in the total Gross domestic product (GDP) and Gross value added (GVA) in Republic of Srpska (in thousands BAM)

\begin{tabular}{|c|c|r|r|r|c|}
\hline Year & GDP & $\begin{array}{c}\text { GVA in } \\
\text { agriculture (in } \\
\text { thousands BAM) }\end{array}$ & GVA total & $\begin{array}{c}\text { In \% from } \\
\text { the total GVA }\end{array}$ & $\begin{array}{c}\text { GVA in } \\
\text { agriculture in \% } \\
\text { from GDP }\end{array}$ \\
\hline 2008 & $8,490,642.00$ & 971,477 & $6,972,026$ & 13.9 & 11.4 \\
\hline 2009 & $8,236,270.00$ & 917,052 & $6,888,593$ & 13.3 & 11.1 \\
\hline 2010 & $8,318,217.00$ & 876,111 & $6,872,931$ & 12.7 & 10.5 \\
\hline 2011 & $8,682,397.00$ & 882,630 & $7,132,366$ & 12.4 & 10.2 \\
\hline 2012 & $8,584,972.00$ & 836,493 & $6,998,183$ & 12.0 & 9.7 \\
\hline 2013 & $8,760,800.00$ & 916,256 & $7,239,409$ & 12.7 & 10.5 \\
\hline
\end{tabular}

Source: Author's calculation according to the Investment-development bank of Republic of Srpska, the Database on the economic indicators, available on http://www.irbrs.net/statistika/Analitika.aspx?tab=4\&lang=cir

Even though the agriculture is considered to be an economic branch which contains the most developmental potentials, in generating the total BDP it participates with just $10-11 \%$. It is obvious from the table that the agricultural participation is in the constant decrease during which the negligible recovery is noted in 2013 when compared to previous year.

However, here it should be taken into consideration that in the spring 2014, Semberija and Posavina, where the main part of the fertile land is located, were affected by immemorial floods, so it is expected for this indicator to decrease.

Keeping in mind the significance of this economic branch the leading of the active politics in agriculture started. The special attention is devoted to the construction of the adequate regulatory frame. The Parliament of Republic of Srpska in July, 2006 EP 2015 (62) 4 (963-974) 
adopted the Strategy of the Agricultural Development of Republic of Srpska till 2015. (The document is available on www.vladars.net/sr-SP Cyrl/Vlada/Ministarstva/mps/ Documents/стратегија развоја пољопривреде PC, entered on $2^{\text {nd }}$ November, 2014).

The strategy includes the following measures:

- The creation of the adequate institutional frame by the reform of the legislation;

- The protective customs policy and the export subvention;

- The stimulation of the agrarian loan market development;

- With the aim of better development monitoring and more adequate support of the agricultural production it is planned to conduct the household registration and classify them to commercial and non-commercial (non-productive). Like this, the establishing of the capacities of these production units is eased. It is expected that, as the time passes the commercial households become the legal persons, and that would enable easier business on the market and easier loan access, and

- The formation of the agrarian budget, from which with the help of the authorized ministry, the assets for the agricultural production subvention would be selected. It is planned for the agrarian budget to be $6 \%$ from the domestic budget revenues lasting for first three years of the enforcement, and later to increase to $8 \%$.

Many laws were adopted - the Law on Agriculture (Official Gazette of Republic of Srpska no 76/06, 20/07, 71/09) and the Law on Security and Direction of the Assets for the Development of Agriculture and Village (Official Gazette of Republic of Srpska no 106/09).

From all undertaken measures, the agricultural producers expect the most from the subsidized production.

The assets provided for these intents are used for the interventions and investments in agriculture. Itemized the whole range of intents for the interventions in agriculture and that (the Law on Security and Direction of the Assets for the Development of Agriculture and Village, article 3) where we have various intents from bonuses in the production of the agricultural products, regressions for the semi-finished products supply, the financing of measures for the agricultural advancement, but also for the financing of the expert services, programs and studies.

Investments in agriculture are encouraged by the loan co-financing to the loans approved to the agrarians by the bank (Subić, Vasiljević, Zorica, Mihailović, 2010). They include the regressions for the loans taken for the fixed and current assets in agriculture, for construction financing and reconstruction of the productive and reproductive capacities, amelioration of the laws and pasture, irrigation systems and financing equipment for the repurchased units of the agricultural products (Mihailović, Cvijanović, Cvijanović Gorica, 2014).

The ministry is obliged to pass a Law on the Conditions and the Way of Gaining Financial Stimulus for the development of agriculture and village, which enables the choice of agricultural households and projects which would be financed. 
The review of the assets appropriation for the stimulation of the agricultural development is given in the following table.

Table 2. The subvention participation for the development of agriculture and village in total budget expenses in Republic of Srpska (in BAM)

\begin{tabular}{|c|c|c|c|}
\hline Year & Subvention & Total budget spending & Participation in \% \\
\hline 2005 & $32,969,611.00$ & $945,600,00$ & 3.49 \\
\hline 2006 & $41,058,077.00$ & $1,098,600,00$ & 3.74 \\
\hline 2007 & $71,514,621.00$ & $1,390,000,00$ & 5.14 \\
\hline 2008 & $80,000,000.00$ & $1,500,000,00$ & 5.33 \\
\hline 2009 & $81,562,000.00$ & $1,600,000,00$ & 5.10 \\
\hline 2010 & $80,000,000.00$ & $1,600,000,00$ & 5.00 \\
\hline 2011 & $60,000,000.00$ & $1,600,000,00$ & 3.75 \\
\hline 2012 & $60,000,000.00$ & $1,825,000,00$ & 3.29 \\
\hline 2013 & $60,000,000.00$ & $1,945,000,00$ & 3.08 \\
\hline
\end{tabular}

Source: Author's calculation based on the budget spending

It is obvious that the subvention amount in agriculture since 2010 decreases in relative amounts which can be explained as a consequence of the problem caused by the economic crisis. According to the Law on Security and Direction of the Assets for the Development of Agriculture and Village which was adopted in 2002, it is planned for the subvention amount to reach $4 \%$ of the budget expenses, which was achieved and exceeded only in the period from 2007-2010.

After that period the assets' amounts to the subventions decrease more and more in relative indicators, even though they stagnated in the absolute, i.e. they increased.

Even though the material support for the agriculture was directed in three different areas - current subventions, investment programs and rural development, the budget assets were marketed on 47 different positions, it can be concluded that the subvention policy had more social than agrarian component. The comprehensively analysis of the given subventions in Republic of Srpska was never done. According to the authorized ministry, more than a half of the assets for the stimulation of the agricultural development were spent for the direct support of the certain products (milk, seeds, and tobacco). Then, the especially negative fact when it comes to the subvention efficiency is that the significant part of the stimulation was given only to the minority of producers (The Strategy of the Agricultural Development of Republic of Srpska, 78).

The special flaw of these subventions is the nonexistence of the coexistent action and comprehensive subvention analysis, which are given on the different governmental levels. The stimuli which are approved by the local autonomy units are not adjusted in the complete agrarian policy with the expenses of the republican governmental level. 
In the end, the fact that Republic of Srpska compensates only $43 \%$ of the needs for wheat, $59 \%$ for corn, $2.9 \%$ for soy, $23.9 \%$ for beef, $32.6 \%$ for pork, $42.6 \%$ for poultry, and $31.2 \%$ for milk (The Strategy of the Agricultural Development of Republic of Srpska, 78), only proves the weak agrarian policy and low subvention efficiency.

If we compare the previous two tables, it can be concluded that the expense amount from the republican budget for the help of agriculture and village does not have any significant part for the agricultural production growth. So the gross value added in agriculture increased during 2010 even though, the subvention amount is decreased by $20,000,000$.

The agricultural part in the creation of GDP in 2013 increased when compared to 2012 for more than one percentage point, even though the subvention amount stayed has not changed.

\section{The importance of subvention for the development of agriculture and village in Republic Serbia}

The Republic of Serbia disposes with 5.1 million ha of the agrarian surface $(0.68$ ha per inhabitant). According to the list from 2012, the number of members and permanently employed at the agricultural households is 1.44 million, which is about $20 \%$ of the population. (The Strategy of the Agricultural and Rural Development of Republic of Serbia for the period from 2014-2024) Republic of Serbia produces surplus in the external exchange of the agricultural products (Mihailović, Cvijanović, Paraušić, Vesna, 2011).

The covering of import by export in the first half of 2014 was $1.8 \%$. (The Ministry of Agriculture and Protection of the Environment of Republic of Serbia www.mpzzs.gov.rs )

Table 3. The agricultural participation in the total Gross domestic product (GDP) and Gross value added (GVA) in Republic Serbia (in billions in RSD)

\begin{tabular}{|c|c|c|c|c|}
\hline Year & GDP & GVA in agriculture & $\begin{array}{c}\text { in \% from the } \\
\text { total GVA }\end{array}$ & $\begin{array}{c}\text { GVA in agriculture in } \\
\text { \% from GDP }\end{array}$ \\
\hline 2008 & $2,661,386.70$ & $237,475.00$ & 10.4 & 8.9 \\
\hline 2009 & $2,720,083.50$ & $218,005.00$ & 9.3 & 8.0 \\
\hline 2010 & $2,881,891.00$ & $245,128.00$ & 9.9 & 8.5 \\
\hline 2011 & $3,208,620.20$ & $292,919.00$ & 10.5 & 9.1 \\
\hline 2012 & $3,348,689.20$ & $279,126.00$ & 9.7 & 8.3 \\
\hline 2013 & $3,618,167.20$ & $344,320.00$ & 11.4 & 9.5 \\
\hline
\end{tabular}

Source: The Strategy of the agricultural and rural development of Republic of Serbia for the period from 2014-2024 Official Gazette of Republic of Serbia no 85/2014

Based on the data in the table, it can be seen that the agriculture takes part in creation the gross value added which goes from 9.3-11\%. However, it is difficult to estimate 
if these changes are the result of the state in agriculture or changes in other sectors (Paraušić Vesna, Cvijanović, Vuković, 2013).

It is a general opinion that the current state in agriculture of Republic of Serbia, their potentials and limits, still show the trend of lower necessary investment, which results in a consequence to get less than possible. (Kosanović, Pejanović, 2010)

No matter of the unused potentials of this economy branch, Serbia has a significant regulatory frame which covers this area. Agriculture is, as a developing potential, recognized in the range of strategic documents. Here it is stated The Strategy of the Agricultural Development of Republic of Serbia (Official Gazette RS no 78/05), The National Program for Agriculture of Republic of Serbia from 2010 to 2013 (Official Gazette RS no 83/10), The National Program of Rural Development from 2011 to 2013 (Official Gazette RS no 15/11) and the Strategy of the Agricultural and Rural Development of Republic of Serbia for the period from 2014-2020.

Based on these strategic documents, the Law on Agriculture and Rural Development was passed (Official Gazette RS no 41/09 and 10/13) and the measures of the agrarian policy. Here we add the (Milovanović 2011) the direct stimuli i.e. measures which influence the market directly, as well as the market support, institutional support and structural support.

The main source of investments in agriculture originates from the agrarian budget which, to people who live in the countryside and those who live from this production, is of the specific significance keeping in mind that nowadays there is no agricultural producer who can survive without the protection and subvention of the state (Simonović, Mihailović, Simonović, 2010).

The main characteristic of the agrarian policy of Republic of Serbia typical for the period from 2000 is its unpredictability. Three phases are characteristic. First phase (2000-2003) is oriented toward the measures of the price support for certain plants (soy, sunflower, sugar beet, wheat) with the absence of other measures of the agrarian policy.

Second phase (2004-2006) is characterized by the abolishment of the price support and it proceeds to the support of the investments and rural development and from 2004 the registration household system was introduced, as a pre-condition for the usage of the budget support for the agriculture. The conditions for listing in the register, and the accomplishment of this right have been changed several times.

Third phase (2007-2009) is characteristic by setting the payments according to surfaces and head of cattle with the part in total agrarian budget which goes over $50 \%$. However, the structure of the assets for the input subvention had been changing dynamically, with the tendency of concentration to the support for diesel fuel and the usage of mineral compost.

The Government of Republic of Serbia passed the Regulation on Division of Stimuli in Agriculture and Rural Development in 2014 published in Official Gazette RS no 8/14 since $29^{\text {th }}$ January, 2014. 
The assets from the Article 2 of this regulation are disposed for the following types of stimuli: direct payments, stimuli for the measures of rural development, special stimuli.

The amounts of the assets to subventions and their participation in the total expenses of the budget of Republic of Serbia are given in the following table.

Table 4. Subvention participation for the development of agriculture and village in total budget expenses in Republic of Serbia (mill. RSD)

\begin{tabular}{|c|r|r|c|}
\hline Year & \multicolumn{1}{|c|}{ Subvention } & Budget Expenses & Participation in \% \\
\hline 2005 & $8,961.20$ & $438,803.20$ & 2.04 \\
\hline 2006 & $11,180.70$ & $529,707.50$ & 2.11 \\
\hline 2007 & $12,754.30$ & $617,625.30$ & 2.07 \\
\hline 2008 & $25,309.90$ & $702,068.30$ & 3.61 \\
\hline 2009 & $16,694.30$ & $746,452.00$ & 2.24 \\
\hline 2010 & $22,863.90$ & $812,473.60$ & 2.81 \\
\hline 2011 & $18,020.10$ & $877,295.10$ & 2.05 \\
\hline 2012 & $29,647.10$ & $980,381.60$ & 3.02 \\
\hline 2013 & $29,866.00$ & $985,749.50$ & 3.03 \\
\hline
\end{tabular}

Source: Author's calculations based on the data on the website of the Ministry of Finance of Republic of Serbia, the Bulletin of Public Finances no 120, August, 2014. Available on the page http://www.mfin.gov.rs/UserFiles/File/bilten\%20javne\%20finansije/bilten-120-web.pdf entered on the 2nd December, 2014.

From the data it can be seen that the biggest budget expenses for subventions from Republican budget were in 2008, when it starts decreasing suddenly. This is a consequence of total economic movements keeping in mind that 2008 and 2009 are the years when the first effects of the economic crisis could be felt. The sharp rise by one percent in total expenses is noted in 2012, and that trend continued in 2013. However, comparing the data from the attached tables there is no clear connection between subventions and newly added value in the observed years. It can be concluded that subventions, even though they are unfortunately inevitable profitability factor in agricultural production of Serbia, they are not of crucial importance for the enhancement of the agricultural role in the total production. It seems that the total role of the agricultural production more depends on the growth of other sectors than on the potential exploitation in the very agriculture.

\section{Results and discussion}

The contribution of agriculture to gross value added in Republic of Srpska in the observed period is constantly decreasing. It ranges from 13.9 to $12 \%$. Even though in 2013 it was higher than in 2012, in 2014 the additional fall is expected, keeping in mind 
that the regions of Semberija and Posavina were affected by great floods. ${ }^{4}$

Even though the agricultural land is considered to be one of the most important resources of Srpska, and that over $57 \%$ of the population lives in and from the countryside, the availability of the agricultural surfaces is estimated to be around 0.952 ha per inhabitant, the agricultural production covers just a small part of the needs for the agricultural products. The cover of the import by export is just $87 \%$.

There is no clear correlation between the subvention volume from the republican budget and revenues to the newly accomplished value. The share of subsidies in total budget expenditures ranges from 3.49 to $5 \%$. Subvention assets, in the observed period had more the form of the social support to the agricultural producers and village, than they had the character of the aimed influence to the development of this economy branch.

Even though the subvention policy declaratively refers to the interventions and investments in production, the assets are mainly directed to the development of the certain products.

Republic of Serbia also disposes with great agricultural surfaces; the availability of the agricultural surfaces is 0.68 ha per inhabitant. More than $50 \%$ of the total population lives in the countryside, while only $20 \%$ of them actively deal with agriculture.

The contribution of the agricultural production to the gross value added in Republic of Serbia in the observed period goes in the interval from 8.0-9.5\%. The noticed oscillations are more the result of changes in other sectors than the changes in agricultural production.

Republic of Serbia produces surplus in the external exchange of the agricultural products, the cover of import by export in the first half of 2014 was $1.8 \%$.

The total subvention amount in the observed period was between 2.04-3.61\%. However, there is no clear correlation between the volume of the newly achieved value in agriculture and subvention amount. The highest value added from $9.1 \%$ was in 2011 , and the subvention amount was among the lowest in the observed period $2.05 \%$ expenditure if the republican budget. ${ }^{5}$

Even though the production would be unprofitable without subventions, the general opinion is that the budget support to the agriculture of Serbia is insufficient and that it significantly lags behind other countries. Besides that, the frequent change of policy of subvention assignment is noticed, which additionally affects the uncertainness of the long-term investments in this sector.

The trend of unfavorable movements in agriculture of Republic of Serbia will probably be continued in the following 2015 having on mind the annunciations Assembly

4 At the time of writing this paper, date for 2014 were not published.

5 It should keep in mind that in the work only expenses from the Republican budget are analyzed, not the expenses of the lower authority levels

EP 2015 (62) 4 (963-974) 
Board of Serbia for agriculture that agriculture will gain 4.06 billion dinars less by the rebalance of budget for 2014 .

\section{Conclusion}

Comparing those two countries it can be concluded that even though the availability of the agricultural land is bigger and the percentage of the employed in Srpska is higher than in Serbia, Republic of Serbia achieves export expenses which bring the conclusion on the greater productivity. However, from the budget of Republic of Srpska for the agricultural production is abstracted more in percentage, the gross value added to the total gross-social product is also bigger.

Then, in none of the countries there is clear tendency of the subvention movements in agriculture. The impression is gained that the direction of the agricultural production is the result before the current oscillations in the budget revenues than the result of the long-term and permanent strategy of the agrarian development.

Also, none of the other countries conducts the adequate analysis of the subvention users, i.e. the effect of assets spending for these intentions, which additionally complicates the long-term leading of the stable expenses policy.

Both observed countries should, based on the strategy which they had already adopted and the legal solutions which are set relatively well, conduct more intense and stable policy of the budget expenses for these intentions, keeping in mind that in both of them the agriculture was identified as a significant production branch with the high developmental potential.

\section{Literature}

1. Bilten javnih finansija br. 120, Ministarstvo finansija Republike Srbije, available at: www.mfin.gov.rs/UserFiles/File/bilten\%20javne\%20finansije/bilten-120-web. pdf,

2. Cvijanović, D., Mihailović, B., Vuković, P. (2014): „Achievements and challenges in rural areas of Serbia before joining the EU“, International Conference: „Achievements and challenges in the food sector and rural areas during the 10 years after EU enlargement“", 12-14 May 2014. Rawa Mazowiecka, Warsaw, Poland, pp 197-207, available at: https://www.ierigz.waw.pl/publikacje/ raporty-programu-wieloletniego-2011-2014/17906,7,3,0,nr-1231-achievementsand-challenges-in-the-food-sector-and-rural-areas-during-the-10-years-after-euenlargement.html

3. Kosanović, N., Pejanović, R. (2010): Konkurentnost i kvalitet hrane, Institut za primenu nauke u poljoprivredi, Beograd, Srbija

4. Mihailović, B., Cvijanović, D., Paraušić, V. (2011): Analysis of export markets and export products of agro sector of Serbia, Simpozionul international cu tema: „Economie agrară şi dezvaltore rurală - realităţi şi perspective pentru Romănia“, 
8-9 septembrie, Bucureşti Romania, pp. 22-31.

5. Mihailović, B., Cvijanović, D., Cvijanović, G. (2014): „Uloga ekološkog savetodavstva u razvoju organske proizvodnje u Srbiji”, XIX Savetovanje o biotehnologiji sa međunarodnim učešćem, zbornik radova, Čačak, 07.-08. Mart 2014. godine, Univerzitet u Kragujevcu, Agronomski fakultet u Čačku, Vol. 60, No. 82, pp. 497-502.

6. Milovanović, M., (2011): Finansijske prepreke i podsticaji razvoju agroprivrede Srbije u pretpristupnom periodu, available at www.ecinst.org.rs/prezentacije/

7. Paraušić, V., Cvijanović, D., Vuković, P. (2013): Analysis of the actual indicators of competitivness in the Serbian agricultural sector, International Conference ,The new solutions of the CAP 2013+ to the challenges of the EU member states agriculture“, 10-12. Jun, Suchedniow, Poland, No.91, pp. 158171, available at: https://www.ierigz.waw.pl/download/9587-r-91.1.pdf kao i link: https:// www. ierigz. waw. pl/ publikacje/raporty-programu-wieloletnie go-2011-2014/1385550891.

8. Pravilnik o uslovima $i$ načinu ostvarivanja novčanih podsticaja za razvoj poljoprivrede i sela, Službeni glasnik Republike Srpske no. 60/2014.

9. Simonović, Z., Mihailović, B., Simonović, D. (2010). „Agrarna politika Srbije i Evropske integracije, International Scientific Meeting: „Regional Development and Demographic Flows of South-East European Countries", XV SCIENTIFIC CONFERENCE, Tematski zbornik, Faculty of Economics Niš, Niš, pp 519-527.

10. Strategija razvoja Poljoprivrede Republike Srpske do 2015.godine, available at www.vladars.net/sr-SP-Cyrl/Vlada/Ministarstva/mps/Documents/strategija razvoja poljoprivrede $\mathrm{RS}$,

11. Strategija poljoprivrednog i ruralnog razvoja Republike Srbije za period 20142024., Službeni glasnik Republike Srbije no. 85/2014.

12. Subić, J., Vasiljević, Z., Mihailović, B. (2010): “Pravci razvoja i investicione preporuke”, in Monography: Strateško planiranje razvoja lokalnih zajednica - model MZ Glogonj, pp. 220-240, ISBN: 978-86-82121-84-8, CIP 502.131.1(497.11), COBISS.SR-ID 176871436.

13. Uredba o raspodeli podsticaja u poljopriovredi i ruralnom razvoju u 2014. godini, Službeni glasnik Republike Srbije, no. 8/2014.

14. Zakon o poljoprivredi, Službeni glasnik Republike Srpske no. 76/2006, no. 20/2007, 71/2009.

15. Zakon o obezbjeđenju i usmjeravanju sredstava za razvoj poljoprivrede $i$ sela, Službeni glasnik Republike Srpske no. 106/09.

16. Zakoni o budžetu Republike Srpske, 2005-2013., available at http://www. narodnaskupstinars.net/stranica/budzet

17. Zakon o podsticajima u poljoprivredi i ruralnom razvoju, Službeni glasnik 
Republike Srbije, no. 10/ 2013.

Websites:

18. The Republic of Srpska Investment-Development Bank www.irbrs.org

19. Government of Republic of Serbia, Ministry of Finance www.mfin.gov

20. Government of Republic of Srpska www.vladars.net

\title{
ANALIZA SUBVENCIJA ZA POLJOPRIVREDU U REPUBLICI SRBIJI I REPUBLICI SRPSKOJ
}

\author{
Ljiljana Jovićc ${ }^{6}$, Nada Kosanovićc ${ }^{7}$, Predrag Vukadinovic ${ }^{8}$
}

\begin{abstract}
Rezime
U radu se vrši komparativna analiza subvencija za poljoprivredu i ruralni razvoj iz republičkog budžeta Republike Srbije i Republike Srpske. Na osnovu analize bruto dodate vrednosti i iznosa subvencija u periodu 2008-2013. zaključeno je da ni u jednoj zemlji nema uzročno-posledične veze između obima subvencija i bruto-dodate vrednost $i$ što ukazuje na neadekvatnu politiku podsticaja.

Pored toga, uočeno je da nema jasnog trenda u visini izdvajanja sredstava kao $i$ strukturi korisnika subvencija što upućuje da politika podsticanja poljoprivrede i sela ni u jednoj zemlji, nema obeležje dugoročno razrađenih ciljeva, nego je više proizvod trenutnih kretanja u javnim prihodima, odnosno kratkoročno definisanih političkoekonomskih prioriteta.
\end{abstract}

Ključne reči : Poljoprivreda, subvencije, Republika Srbija, Republika Srpska

6 Vanredni professor, dr Ljiljana Jović, Visoka poslovna skola Novi Sad, Vladimira Perića Valtera br. 4, 21000 Novi Sad, Telefon: +381 65608 916, E-mail: joviclj@hotmail.rs

7 Dr Nada Kosanović, naučni saradnik, Institut za primenu nauke u poljoprivredi, Bulevar Despota Stefana br. 68 B, Beograd, Srbija, Telefon: + 38164240 8653, E-mail: nada.kosanovic@gmail.com

8 Docent, dr Predrag Vukadinović, Univerzitet Singidunum, Poslovni fakultet. Danijelova br. 32, Beograd, Srbija, Telefon: +381 63216 908, E-mail: pvukadinovic@singidunim.ac.rs 